SPIERENBURG, PIETER, From Amsterdam to Auburn: An Explanation for the Rise of the

Prison in Seventeenth-Century Holland and Nineteenth-Century America, Journal of Social History, 20:3 (1987:Spring) p.439

\title{
FROM AMSTERDAM TO AUBURN AN EXPLANATION FOR THE RISE OF THE PRISON IN SEVENTEENTH-CENTURY HOLLAND AND NINETEENTH. CENTURY AMERICA
}

The prison and its origins have aroused a good deal of historical interest in recent years. ${ }^{l}$ The resultant literature, to which scholars from various disciplines have contributed, is often labelled as 'revisionist'. The label is applied because of a major common characteristic: although these studies diverge on several points, they all react against an older model which presented the rise of the prison simply as the result of the benevolent endeavors of humanitarian reformers. The reaction was of course long overdue. In other fields of historical inquiry serious analysis likewise has been substituted for a naive desire to praise or to blame the actors involved. A disadvantage of the revisionist approach, on the other hand, is its tendency to create a mirror-image of the humanitarian argument. The reformers are now seen as 'bad guys', indifferent to the fate of convicts and bent on creating opportunities for economic gain. The ensuing dichotomy between good and bad should certainly be overcome. ${ }^{2}$ Nevertheless, the recent literature represents a very valuable contribution to historical scholarship, because it has placed the rise of imprisonment more firmly in its social context. In America Rothman dealt with the interdependence between various types of institutions and related their emergence to changing attitudes in the Jacksonian era. ${ }^{3} \mathrm{~A}$ different group of scholars, notably Conley and Miller, stressed the role of economic factors in the emergence of prisons. ${ }^{4}$ On the other side of the Atlantic authors such as Foucault, Stekl and Ignatieff put forward arguments which were divergent as well but all centered around the social needs for discipline and control. ${ }^{5} \mathrm{My}$ own work stresses the importance of state formation processes. ${ }^{6}$

The present article attempts to take the discussion further by making a beginning at transatlantic comparison. The comparison will focus on the causes for the establishment of prisons rather than on the details of their functioning once they had been established. My central question is: what was the social context which favored the rise of the prison in Europe and America, respectively? This, it is hoped, may provide a new impetus for historical theorizing about the origins of imprisonment.

The essay deals with Europe first. The earliest phase of Europe's experience with imprisonment will be elucidated, with Amsterdam as the main example. Thereafter the extent to which the European experience sheds light on the problem of the rise of imprisonment in America will be discussed. The first enterprise is a necessary prerequisite for the second. At first sight it may seem only natural to discuss American developments in the early nineteenth centuruy together with simultaneous developments on the other side of the Atlantic. I will demonstrate, however, that the earliest phases of the history of the prison on the two continents are to be situated in the early nineteenth century and in the seventeenth, respectively. In order to discuss causation, therefore, America 
SPIERENBURG, PIETER, From Amsterdam to Auburn: An Explanation for the Rise of the

Prison in Seventeenth-Century Holland and Nineteenth-Century America, Journal of Social History, 20:3 (1987:Spring) p.439

around 1800 should be compared primarily with seventeenth-century Europe and more specifically with Amsterdam. An older study by Rusche and Kirchheimer acknowledged this difference in timing, but later it tended to be forgotten. ${ }^{7}$ In his book on madness, published in 1961, Foucault devoted considerable attention to imprisonment in early modern France, but these data hardly play a role in his 1975 study of French prisons from the Revolution onwards. ${ }^{8}$ Therefore it is necessary to pay attention once more to the long-term process in Europe, beginning around 1600. First I will explain, on a general level, how and why the prison emerged in a number of Western-European countries. This is followed by citing an illustrative case, that of Amsterdam. The choice of Amsterdam is not merely one of convenience, since the city was the major model for the rest of the European continent. The Dutch experience is the one that may shed light on developments in North-East America in the late eighteenth and early nineteenth centuries.

\section{Prisons in early modern Europe}

A number of German legal historians, writing in the early decades of the twentieth century, dealt with the origins of imprisonment from a European perspective. Several other scholars, inspired by this tradition, devoted articles and a feiw monographs to individual institutions, notably German and Dutch. ${ }^{9}$ All agreed, and for sound reasons, that houses of correction were the first true prisons. The physical restriction of another person's freedom may be a phenomenon as old as mankind itself and confinement in an enclosed space, a more specific act, is probably very ancient too. But the houses of correction, inaugurated from the second half of the sixteenth century onwards, were the first institutions in which the majority of inmates were there to be chastized for a certain time. These houses were different from earlier places of confinement. In the European middle ages people were locked up in dungeons, towers or forts, but imprisonment as a result of a judgment in a trial was very infrequent. The majority of inmates were either kept as a hostage for their creditors or provisionally detained as suspects. These two functions continued to be served in the early modern period but not by the houses of correction. In eighteenthcentury London, for example, debtors were locked up in King's bench. ${ }^{10}$ Houses of correction, on the other hand, held several categories of deviants such as beggars, prostitutes and thieves.

The historical sequence in Europe justifies a distinction, for analytical purposes, between two Weberian ideal types: jail and prison. A jail mainly holds debtors and persons under provisional detention (in anticipation of or during a trial, and awaiting execution); a few may have been incarcerated for penal purposes. Although some inmates are detained for quite some time, the building is not expressly equipped for long-term stays. There are no arrangements for keeping the inmates busy. A prison primarily keeps delinquents or other deviants who have been sent there to serve a term for purposes of chastisement or correction. The inmates are subjected to a specific regime, which in early modern Europe was usually centered on compulsory labor. The institution is equipped to occupy its inmates, although difficulties may arise in practice. Houses of correction 
SPIERENBURG, PIETER, From Amsterdam to Auburn: An Explanation for the Rise of the

Prison in Seventeenth-Century Holland and Nineteenth-Century America, Journal of Social History, 20:3 (1987:Spring) p.439

correspond to this ideal type and therefore they can be designated as prisons. In cases where the majority of inmates to be chastised are delinquents sentenced in a criminal trial we may speak of a criminal prison.

The emergence of the house of correction was the culmination of a transformation of attitudes toward the poor in general and beggars and vagrants in particular. In the course of the sixteenth century poverty was increasingly viewed in secular terms as a threat to public order, in Catholic as well as Protestant countries. Although this transformation of attitudes was also influenced by economic developments, it was primarily related to processes of state formation. By the sixteenth century, as a direct concomitant of state formation processes, Western Europe as a whole was a relatively pacified entity for the first time. Pacification served as a major precondition for the rise of confinement. The foundation of houses of correction implied at least two changes of policy. First, the institutions constituted a new and alternative option for dealing with those people who in an earlier period would also have been treated as deviants. In this earlier period they might have been banished, for instance, because the problems of a neighboring town or territory did not bother the judges. In a more pacified society, however, the idea that unwanted atrangers might be kept off the roads is more likely to arise. This idea was realized in the house of correction, being a spatial solution for public order problems. Second, the house of correction was a more visible symbol of repression. It testified to the determination of the authorities to deal with new categories of deviants as well. The latter were the beggars and vagrants, whom the simultaneous change of attitudes toward poverty and idleness had put into such an unfavorable position. In a more pacified society, where private warfare and vendettas have been subdued, it is easier for the authorities to tackle new problems of public order."I

Thus the first prisons in Europe were inaugurated because a specific stage in state formation piocesses, a relative monopolization of violence by monarchs and patriciates, had been reached. England led the way from the middle of the sixteenth century onwards and the Dutch Republic followed around 1600. In the course of the seventeenth century houses of correction were established in many towns in continental Europe. Although most towns did not go so far as to adopt the differentiation that will be shown to have characterized Amsterdam, separate wards were not uncommon. And the three main elements of the Amsterdam prison regime - compulsory labor, physical means of discipline and moderate publicity - were features of houses of correction everywhere.

The emergence of the criminal prison - another development marked in Amsterdam - can also be traced in the Dutch Republic as well as abroad. Most cities in Holland used their houses of correction increasingly as a penal institution from the late seventeenth century onwards, and the institutions severed their ties with poor-relief. The landward provinces, which founded houses of correction in the early eighteenth century, primarily listed delinquents as inmates to be. In seven sample regions from the territory of the Republic between 1700 and 1811 imprisonment in a house of correction accounted for 15.2 pct. of the sentences. ${ }^{12}$ In the German countries the criminal prison emerged along other lines, but its rise was equally marked. Originally, houses of correction were not 
SPIERENBURG, PIETER, From Amsterdam to Auburn: An Explanation for the Rise of the

Prison in Seventeenth-Century Holland and Nineteenth-Century America, Journal of Social History, 20:3 (1987:Spring) p.439

meant for convicts and for a long time the governors conducted a struggle against the judicial bodies who wished them to receive delinquents too. The governors notably opposed the confinement of criminals who had received corporal punishment at the hands of the executioner, which would attach infamy to the institution. By the first half of the eighteenth century, however, the courts had won this struggle and imprisonment in a house of correction had become a common penal option. Houses of correction in the Habsburg Empire likewise evolved into penal institutions. ${ }^{13}$ The hôpitaux généraux of France remained a sort of asylum, but in the second half of the eighteenth century they were supplemented by new prisons for beggars, which in no way had the character of asylums. In addition, the galleys were put out of service and from 1748 onwards the bagnes were in fact workhouses for delinquents. ${ }^{14}$ On a European scale, therefore, the rise of the prison should be situated in the seventeenth and that of the criminal prison in the eighteenth century.

This overview may be supplemented by empirical data derived from a casestudy. The preceding discussion suggests which features of houses of correction should receive emphasis. The first question is of course: when was the institution established? Further, we have to know whether we may call it a prison: were the inmates really incarcerated or did they enter more or less voluntarily? Was there a labor program or did the institution rather resemble a jail? The next question is 'who were the inmates'? They may be delinquents or other deviants; various categories may be incarcerated together or differentiation may prevail. The length of a prisoner's stay is another crucial variable. Finally, it is important to know whether confinement played a considerable role or only a marginal one in the penal system. For Amsterdam, all these questions can be answered.

\section{The Amsterdam Institutions}

As noted above, Amsterdam was exemplary. In fact the city served as a model both within the Republic and abroad, which is attested, among other things, by the large number of foreign visitors to the houses of correction. In the early years of the seventeenth century books and pamphlets about the Amsterdam rasphouse appeared in French and German. ${ }^{15}$ Various houses elsewhere in the Republic were consciously modeled on those of Amsterdam. This was the case as early as 1596 in Leiden and as late as 1710 when the Estates of Gelderland founded a prison. ${ }^{16}$ Several towns abroad oriented themselves in Amsterdam; directly or indirectly by taking Holland as a whole for a model. The Antwerp magistrates did so in 1613 and the authorities in the German city of Celle did the same in 1732 .

The existence of J.N. Jacobsen Jensen's list of foreign visitors ${ }^{17}$ enables me to provide a quantitative illustration of the public's interest. It is an inventory of foreigners known to have travelled in the Netherlands prior to 1850 . Those coming after 1596, the year in which the rasphouse was opened, number 366 , of whom forty-three did not visit Amsterdam. Another forty-five refrained from specifying the places they went to within the city. The remaining 278 are the ones that concern us. They figure in table 1 . Over the entire period a third visited one or more of the houses of correction. However, throughout the seventeenth 
SPIERENBURG, PIETER, From Amsterdam to Auburn: An Explanation for the Rise of the

Prison in Seventeenth-Century Holland and Nineteenth-Century America, Journal of Social History, 20:3 (1987:Spring) p.439

century almost one half did so. This is a relatively high number in view of the many other places of interest. Moreover, these visitors came to Amsterdam for all kinds of different purposes. After 1700 interest in the houses of correction steadily declined. At the end of the eighteenth and in the early nineteenth century the newly built workhouse attracted most visitors.

TABLE 1

Visitors to a house of correction in Amsterdam, 1596-1849

\begin{tabular}{lccc}
\hline period & $\begin{array}{c}\text { visitors to } \\
\text { the city } \\
\text { abs. }\end{array}$ & \multicolumn{2}{c}{$\begin{array}{c}\text { visitors to a } \\
\text { house of correction }\end{array}$} \\
$1596-1649$ & 26 & $a b s$. & pct. \\
$1650-1699$ & 45 & 12 & 46 \\
$1700-1749$ & 30 & 21 & 47 \\
$1750-1799$ & 77 & 11 & 37 \\
$1800-1849$ & 100 & 24 & 31 \\
total & 278 & 23 & 23 \\
(Source: Jensen, 1919) & & 91 & 33
\end{tabular}

Amsterdam served as a model not because for some mysterious reason others sought to emulate it, but because the city catered to social needs that were equally felt elsewhere. The house of correction represented one possible solution to problems of control which were common to Western-European countries. Control of the marginal population and discipline of the poor figured prominently among those problems. These were the objectives of Amsterdam's first house of correction, the foundation of which had been decided upon in 1589 . Seven years later the first inmates arrived. Although the necessity for an alternative punishment for young thieves had been stressed as the primary motive for establishing a house of correction, beggars and vagrants constituted the principal category of inmates in the early decades of its existence. This emerges from the work of Pontanus, published in $1611 .^{18} \mathrm{His}$ book is the first in a series of descriptions proclaiming the wonders of the expanding metropolis. According to Pontanus, the problem caused by widespread begging and vagrancy in Holland lay behind the inauguration of the house of correction. He specifically referred to a placard against beggary issued by the provincial Estates in December $1595 .{ }^{19}$ That beggars comprised the majority of inmates in the early seventeenth century is confirmed by a booklet, published in 1612 , which is devoted entirely to the house of correction. It speaks only of persons asking for alms, being unwilling to work. ${ }^{20}$ In 1614 the court ordered the almshouse provosts to pick up everyone illegally asking for alms or wandering about idly and put them in the house of correction without trial. Those rounded up were only taken to court if it was the person in question's fourth arrest. ${ }^{21}$

By this time Amsterdam boasted two houses of correction, since a separate prison for women had been opened in 1597. Thus the city went on a course toward a differentiated system of institutions. The prison for women was called 
SPIERENBURG, PIETER, From Amsterdam to Auburn: An Explanation for the Rise of the

Prison in Seventeenth-Century Holland and Nineteenth-Century America, Journal of Social History, 20:3 (1987:Spring) p.439

the spinhouse and its male counterpart was soon referred to as the rasphouse. Another major step in the differentiation process was taken in the 1650's, when beggars received their own prison. In 1650 a "workhouse for poor children" was opened and in August 1654 it was officially designated as a prison for beggars and vagabonds. ${ }^{22}$ Henceforth the almshouse provosts were ordered to take those arrested by them to the workhouse. ${ }^{23}$ Its inmates were beggars of both sexes.

From then on the rasphouse and, to a lesser extent, the spinhouse were truly criminal prisons. The differentiation of institutions was already self-evident to Olfert Dapper, whose description of Amsterdam was published in 1663. Speaking about the rasphouse, he begins by quoting Pontanus. But he immediately adds that he thinks the latter's views on the motives for the house's foundation are incorrect: "It seems rather hard and almost inhuman to put beggars (though some used to steal under that guise) to such heavy labor" [i.e. rasping wood]. ${ }^{24}$ The real motive, he continues, was "perhaps" that schepenen were forced to hang many young thieves, and looked for an alternative. The word "perhaps" betrays the fact that Dapper's conclusions were not based on historical research. For him the connection prison - heavy labor - crime was simply a matter of course. In the less serious case of vagrancy imprisonment took place in the workhouse. At the same time Hans Bontemantel, who was himself schepen for several years, testified that the court considered confinement a normal part of the penal system. Imprisonment in a house of correction figures in his rank-order of penalties as a matter of course between whipping indoors and exposure on the pillory. ${ }^{25} \mathrm{At}$ the end of the century Caspar Commelin sealed the preceding development by inventing a new collective name for the houses of correction. They had always been designated, together with the charitable institutions founded in the middle ages, as godshuizen. Commelin separates them from this category and calls them "houses of justice". 26

One more change was to occur: the detachment of confinement on request from the prison system. From the early years onward those inmates who were not vagrants or delinquents were confined at the instigation of relatives, with the court merely authorizing it. Many of the inmates belonged to the lower classes, but this was not the case with every 'licentious' and 'untractable' person. Even before the opening of the rasphouse there was talk of 'children of good parents' being placed there and in both the rasp and spinhouse a separate ward, called the 'secret place', was soon instituted for this purpose. Its inmates were not obliged to work. It is significant that in these early years respectable families were prepared to have a member confined under the same roof with more marginal persons. But as the houses of correction increasingly evolved into criminal prisons in the course of the seventeenth century, every form of confinement there became associated with the infamous sphere of justice. At the end of the century this led to the emergence of a separate type of institution for confinement on request. Throughout the Republic this institution became known as the beterhuis. Although the Amsterdam spin and workhouse continued to accommodate prisoners confined on request, a new institution for the elite founded in 1694. This Amsterdam beterhuis was only semi-private; the city leased it to the manager.

At the close of the seventeenth century, therefore, Amsterdam had a 
SPIERENBURG, PIETER, From Amsterdam to Auburn: An Explanation for the Rise of the

Prison in Seventeenth-Century Holland and Nineteenth-Century America, Journal of Social History, 20:3 (1987:Spring) p.439

differentiated prison system for male and female criminals (including beggars and vagabonds who were legally delinquents as well) and persons exhibiting undesirable behavior. From the 1650's onwards the rasphouse was unequivocally a criminal prison. The emergence of confinement in private institutions marked the development whereby the older houses became exclusively tools of justice. In the eighteenth century even the rasphouse's secret place served as such a tool. It harbored those among the condemned whom the court wished to bar from public access. These included persons convicted of sodomy, in so far as they were spared the death penalty. The Amsterdam rasphouse may have been the first truly criminal prison in world history.

The differences between the Amsterdam houses of correction and medieval jails can be illuminated further by a look at the former's regime. The programs were fairly uniform. Only the secret places and the beterhuizen which succeeded them stand out in this respect, but these are of less concern here. A veritable prison regime was imposed on those confined in the other institutions. They were compelled to work and hence contribute to the cost of their stay. From the early seventeenth century onwards the labor program of the first house of correction consisted solely of rasping wood (hence its name). Blocks of Brazil redwood had to be grated to a pulver, which was used as raw material in the paint industry. The raspers were obliged to produce a minimum amount. This counted as very hard work, as Dapper's remark indicates. The type of work done by the prisoners in the workhouse was lighter. It included hemp-beating, knitting nets and weaving coarse linen and canvas. Sacks were made from the canvas to pack the red powder which the other house of correction produced. ${ }^{27}$ The nature of the labor program in the spinhouse is evident from its name. Apart from labor, religious exercises and instruction originally had a prominent place in the projected daily programs. Several historians have stressed this feature, but in fact the original ambitious schemes were soon abandoned of necessity. According to Dapper, in the rasphouse the religious books were simply laid into the cells. One does not expose a preacher or schoolmaster to "a bunch of raging and wild people. ${ }^{28}$ The oldest prison was no exception to the rule that practice does not conform to all the rhetoric of the founders.

Visitors were regularly admitted into the houses of correction for a fee. The public could see the condemned in action. It was a reflection of the relatively public character of the entire penal system. Still, the penalty of imprisonment was decidedly less theatrical than punishment on the scaffold. The rise of the prison is a clear expression of the long process which ultimately led to the nineteenth-century privatization of repression. Its twin process was the reduction of the physical element in punishment, and there the houses of correction represented an intermediary stage too. Beatings were a common feature of the maintenance of discipline in the institutions, but still imprisonment was the first form of serious punishment which did not primarily have the infliction of physical suffering as its purpose.

What remains to be demonstrated is the relatively important role of the houses of correction within the penal system in Amsterdam. The available quantitative data make this clear enough. Jean Jüngen studied the court's sentences for the years 1600 and 1614. He found five condemnations to the rasphouse in 1600 
SPIERENBURG, PIETER, From Amsterdam to Auburn: An Explanation for the Rise of the

Prison in Seventeenth-Century Holland and Nineteenth-Century America, Journal of Social History, 20:3 (1987:Spring) p.439

out of a total of 130 cases. In 1614 six convicts out of 128 were sent to a house of correction. Three were women condemned to the spinhouse. ${ }^{29}$ These are moderate numbers. In those years the majority of inmates were not delinquents serving a court's sentence. My own research covers the years 1650-1750, when all three houses of correction were in operation. It yielded two bodies of data: a complete series of all cases ending in a scaffold punishment and a sample of the remaining cases..$^{30}$ The judgment often consisted of several penalties combined. This was notably so in the scaffold series, which would otherwise have counted no confinements at all. The Confinements in the sample include both single cases and those in which it was combined with another penalty (usually banishment).

TABLE 2

Frequency of Confinement in Amsterdam, 1651-1750

A. In the scaffold series

\begin{tabular}{|c|c|c|}
\hline period & $\begin{array}{l}\text { number of } \\
\text { confinements }\end{array}$ & $\begin{array}{l}\text { percentage from } \\
\text { all public } \\
\text { sentences }\end{array}$ \\
\hline
\end{tabular}

$\begin{array}{lrr}1651-1660 & 95 & 37,4 \\ 1661-1670 & 161 & 53.5 \\ 1671-1680 & 92 & 48.9 \\ 1681-1690 & 102 & 49.0 \\ 1691-1700 & 170 & 47.5 \\ 1701-1710 & 65 & 34.6 \\ 1711-1720 & 160 & 34.2 \\ 1721-1730 & 202 & 43.5 \\ 1731-1740 & 129 & 46.1 \\ 1741-1750 & 147 & 52.5\end{array}$

B. In the sample $(N=500$ in each period)

period

percentage of confinement

$1651-1683$

17.4

$1684-1716$

20.8

$1717-1749$

20.8

(source: Sententie- and Confessieboeken, Gemeente-archief Amsterdam.

Table 2 shows that imprisonment followed upon chastisement on the scaffold in a number of cases fluctuating between a third and more than one half. The fluctuations do not betray a specific pattern. It should be noted that the cases without confinement include those where the judgment was capital (13 percent of the entire scaffold series). In the sample the percentage of condemnations to a house of correction stays more or less stable at about one fifth. ${ }^{31}$ Since the Amsterdam court judged a declining number of cases in the first half of the eighteenth century, the absolute number of confinements in non-public cases dropped as well. Considering the approximate total of punishments, the annual 
SPIERENBURG, PIETER, From Amsterdam to Auburn: An Explanation for the Rise of the

Prison in Seventeenth-Century Holland and Nineteenth-Century America, Journal of Social History, 20:3 (1987:Spring) p.439

FROM AMSTERDAM TO AUBURN

average of condemnations to a house of correction in non-public cases in the second half of the seventeenth century was about seventy-five. In addition about twelve scaffolded delinquents were imprisoned yearly. After 1700 the total number of confinements declined.

\section{TABLE 3}

Long-term confinements in Amsterdam, 1651.1750

A. Scaffold series (percentages are from all sentences including confinement)

\begin{tabular}{llrrr} 
period & \multicolumn{2}{c}{$\begin{array}{c}\text { number of terms of } \\
\text { five years or longer } \\
\text { pct. }\end{array}$} & abs. & \multicolumn{2}{c}{$\begin{array}{c}\text { number of terms of } \\
\text { ten years or longer } \\
\text { pct. }\end{array}$} & $\begin{array}{r}\text { abs. } \\
\hline 1651-1660\end{array}$ & 41.0 & 39 & 14.7 & 14 \\
$1661-1670$ & 28.7 & 46 & 4.3 & 7 \\
$1671-1680$ & 21.8 & 20 & 6.6 & 6 \\
$1681-1690$ & 58.9 & 60 & 29.5 & 30 \\
$1691-1700$ & 59.4 & 101 & 25.9 & 44 \\
$1701-1710$ & 56.9 & 37 & 26.1 & 17 \\
$1711-1720$ & 81.8 & 131 & 51.2 & 82 \\
$1721-1730$ & 75.3 & 153 & 44.8 & 91 \\
$1731-1740$ & 78.3 & 101 & 53.5 & 69 \\
$1741-1750$ & 68.0 & 100 & 52.4 & 77
\end{tabular}

B. Sample (percentages are from all confinements)

\begin{tabular}{lcc} 
period & $\begin{array}{c}\text { percentage } \\
\text { of terms of } \\
\text { five years or longer }\end{array}$ & $\begin{array}{c}\text { percentage } \\
\text { of terms } \\
\text { ten years or }\end{array}$ \\
\hline $1651-1683$ & 0.9 & - \\
$1684-1716$ & 6.8 & 2.3 \\
$1717-1749$ & 18.5 & 4.4
\end{tabular}

(Source: Sententie- and Confessieboeken,Gemeente-archief Amsterdam).

Table 3, however, shows that a higher frequency of relatively long terms emerged in the course of the eighteenth century, a development especially marked among the non-public cases. This formed a reaction to the drop in condemnations and it saved the houses of correction from a relative depopulation. The choice of penal options as such was apparently less influenced by capacity-considerations. The combination of the various quantitative trends had its most fateful effect on the rasphouse. The institution's character as a prison for serious delinquents was reinforced in the first half of the eighteenth century. From the 1650's through 1670's an annual average of thirty-eight convicts entered the rasphouse, seven of whom mounted the scaffold. From the 1720's through 1740 's the yearly number of scaffolded delinquents confined there was still about seven: this time out of twelve and burdened with longer terms. It should be noted that the real length of a stay in prison was usually shorter than the term set. Most inmates of the 
SPIERENBURG, PIETER, From Amsterdam to Auburn: An Explanation for the Rise of the

Prison in Seventeenth-Century Holland and Nineteenth-Century America, Journal of Social History, 20:3 (1987:Spring) p.439

houses of correction received reduction for good behavior. This custom had a function similar to the later American 'good time' system. ${ }^{32}$ But real length correlated with official term.

It is clear from these figures that the houses of correction played a major role in Amsterdam's penal system. The figures do of course refer to sentenced delinquents only; beggars especially, who were usually confined without a trial, are not included. Further research is needed in order to know to what extent other European cities conformed to the Amsterdam pattern.

Although confinement played a considerable role in the penal system of the Dutch metropolis, it should not be forgotten that public executions and corporal punishment existed alongside it. It was only toward the end of the eighteenth century that a heightened sensitivity with regard to the sight of the scaffold became manifest. ${ }^{33}$ This was the case throughout Europe. What happened in Europe after about 1800 , therefore, amounted to a new transformation in penal practices and attitudes toward repression, rather than a continuation of the preceding development. Eventually, corporal punishments would be abolished and the death penalty executed indoors. While physical punishment was being debated, experiments were made with new forms of imprisonment which corresponded more closely to the ideal of a privatized repression. The characteristic type of new prison was the penitentiary, a word first used in Britain in the second half of the eighteenth century. ${ }^{34}$ The emphasis shifted from compulsory labor and semi-publicity to regimentation, avoidance of contact and, above all, confrontation of the offender with his inner self. Solitary confinement was to promote this confrontation, while the new interest in regimentation and surveillance was reflected most tellingly in the panoptic principle. The experimentation-phase of the first half of the nineteenth century was further characterized by a fresh enthusiasm for the best possible way to set up a prison. This explains the various projects on paper such as Bentham's and the frequent journeys of orientation. Visits to prisons were not only made within Europe but also to America. At this point it may be appropriate to shift the focus to the latter continent.

\section{America before the prison: New Netherland and its neighbors}

There is a good reason to consider New Netherland first: the prison system of New Amsterdam's mother-city was already in full operation when the British seized the colony from the Dutch. If there had been houses of correction along the Hudson river by then, we might conclude that imprisonment was easily exportable to distant societies. Compared to the early history of New England, the history of New Netherland has been neglected - certainly as far as criminal justice is concerned. It is worthwhile to dig a little into it. Could Amsterdam's prison system have been exported to the New World in the seventeenth century?

This is not entirely inconceivable, if we realize that the Dutch East India Company opened a spinhouse in Batavia in 1642. But this institution was not a criminal prison and never became one. It was founded because some Christian women led a "scandalous, dirty and licentious life" and its main purpose seems to have been to provide men with the means of ridding themselves of their 
SPIERENBURG, PIETER, From Amsterdam to Auburn: An Explanation for the Rise of the

Prison in Seventeenth-Century Holland and Nineteenth-Century America, Journal of Social History, 20:3 (1987:Spring) p.439

wives. ${ }^{35}$ Its character only faintly resembled that of contemporary houses of correction in Holland. ${ }^{36}$ If the founding phrase has any real meaning beyond that of a routine statement, it can be argued why such a spinhouse was not opened in New Amsterdam. The need for protecting the reputation of Christians was less urgent there. The European and Indian communities had little mutual contact save in war. Moreover, the former regarded the latter as savages, to a greater extent than the Asian peoples whom the East India Company dealt with. Consequently, the whites in America were less conscious of having a standard to maintain. The Dutch in New Netherland lacked the Puritans' obsession with morals offenses. Occasionally a prostitute was banished, but on the whole it was not too spectacular. ${ }^{37}$

As New Amsterdam had no spinhouse, it did not establish anything resembling its mother-city's rasphouse either. The New Netherland book of placards, which was begun in 1638 when Willem Kieft became governor, does not refer to such an institution. A few placards threaten with labor in a chain gang along with black slaves, and these laws are significant. ${ }^{38}$ Working in a chain gang, or opus publicum, was known in Europe too and as a penalty it was older than the house of correction. Where the latter existed, however, opus publicum normally fell into disuse. As long as non-capital, serious offenders were occasionally employed to build fortifications and roads, there was even less need for a prison. The absence of a prison from New Amsterdam is attested by a sentence in 1647 when Pieter Stuyvesant condemned one Michiel Piquet to a term of eighteen years in a house of correction. Piquet was sent over to old Amsterdam to be confined in the rasphouse. $^{39}$

This event took place in the first of Stuyvesant's seventeen years of office, when a proper court had not yet come into existence. What about the later years? The city of New Amsterdam got its own court of justice in 1653 and similar courts were subsequently instituted in the settlements on Long Island. ${ }^{40}$ New Amsterdam court records are largely unresearched and it would require a largescale investigation to analyze them thoroughly. Such an investigation would certainly be worthwhile, but for our present purposes it is not necessary to perform it. It is clear enough that these records deal with anything but imprisonment. I examined the year 1663 , the last of uninterrupted Dutch rule. ${ }^{41}$ Slightly more than half of the cases are civil suits or at least conducted by a private prosecutor. In the others the schout is the prosecutor. These are still minor cases and almost always the penalty is a fine. In addition we should consider the activities of the New Netherland Council, which still dealt with judicial matters as well. The contemporary index of the 1663 council minutes contains a page which O'Callaghan lists as 'register of sentences. ${ }^{12}$ The record has twelve entries. Four refer to decisions in conflicts over possession of land or related financial matters. Two men are banished from the province for reasons which remain unclear. One is prosecuted for slander but his begging forgiveness settles the matter. In three cases the extant fragments do not permit a conclusion about their contents. Two men, finally, are condemned for stealing from a ship. They are to be whipped and ordered to return to their service until the money can be restituted. ${ }^{43}$

An exhaustive examination of the records may reveal a few cases of imprisonment, but as a penalty it must have been very rare. ${ }^{44}$ Other courts 
SPIERENBURG, PIETER, From Amsterdam to Auburn: An Explanation for the Rise of the

Prison in Seventeenth-Century Holland and Nineteenth-Century America, Journal of Social History, 20:3 (1987:Spring) p.439

probably followed a similar sentencing policy. Only a tiny fraction of the cases judged by the court of Beverwijk were serious offenses and these were punished corporally ${ }^{45}$ The only location for confinement in New Amsterdam was in the town hall..$^{46}$ This was a normal practice adopted from the mother-city: in Amsterdam and other Dutch towns the court convened in the town hall, in the basement of which delinquents in provisional detention were kept together with debtors. These places were jails and so was the place in New Amsterdam's town hall; it was certainly not a prison. There is no trace of a house of correction in New Amsterdam.

Conversely, at least in name, such houses do appear in other colonies at that time. The Massachusetts authorities ordered the building of a house of correction in 1632 and again in 1655, this time for each county. A similar order was given in Pennsylvania in 1683. But the name used should not deceive us. The houses which were constructed or designated were no more than ordinary jails, as was often the case with nominal houses of correction in contemporary England. The one in Philadelphia was actually denoted as a 'cage'. The institution which probably came nearest to a house of correction in seventeenth-century America was the Boston almshouse of 1685 , which also served as a place of confinement. 47

Almshouses were indeed the first 'asylums' in Colonial America, appearing on the scene from the late seventeenth century onwards. ${ }^{48}$ The Reformed diaconie of New Amsterdam established a refuge for the poor as early as 1653-5, first in a house then in a bouwerie. ${ }^{49}$ Rothman included almshouses in the network of institutions he studied, but as more or less voluntary places, I would rather consider them separately from prisons, workhouses and madhouses. He further stresses that during the Colonial period most of the poor were assisted at home or in neighboring households. ${ }^{50}$ This, however, is a trivial remark, since it has been common practice everywhere in most periods of history. More important are the existence of institutions as such and the mentality which they express. Rothman explains that Colonial attitudes to the poor were not basically repressive, a position also taken by Gary Nash, who argues that in Philadelphia the change toward a new attitude took place on the eve of the Revolution. ${ }^{51}$ That is the crucial point. A more benevolent attitude to the poor similarly prevailed in Europe before the sixteenth-century transformation. Still medieval Europe had its voluntary godshuizen: almshouses and hospitals. It is clear that charitable institutions do come earlier than prisons. For Europe the actual 'discovery of the asylum' should be situated in the thirteenth century.

As for New York, it does not seem to have played an advanced role among the colonies. ${ }^{52}$ In his synthesis of Colonial New York's history, Michael Kammen states that the province remained predominantly Dutch for a generation after $1664 .{ }^{53}$ Even so, this means that the reminiscence of Amsterdam had finally faded away by the time of Leisler's rebellion. Only in 1736 did New York City erect its first house of correction. ${ }^{54}$ The conclusion must be that there are no grounds for the assumption that the Amsterdam prison system had specific influence upon repression in the New World. How could it have been otherwise? For one thing, Stuyvesant was a Calvinist and a soldier, while the founding fathers of the rasphouse were magistrates and liberals. ${ }^{55}$ More important considerations have to do with social structure. The emergence of houses of correction in Europe 
SPIERENBURG, PIETER, From Amsterdam to Auburn: An Explanation for the Rise of the

Prison in Seventeenth-Century Holland and Nineteenth-Century America, Journal of Social History, 20:3 (1987:Spring) p.439

presupposed a certain stage of state formation and social differentiation, as explained above. This type of social structure did not characterize seventeenthcentury America. By 1690 New York City had a few thousand inhabitants and, in many respects, resembled a late medieval town. Like other major Colonial cities it had barely outgrown frontier conditions or differentiated itself from the countryside. ${ }^{56}$ The province as a whole was far from pacified or stable, consisting of isolated communities, semi-feudal manors and Indian tribes. No wonder this society only felt a need for quick justice.

\section{The rise of the prison in America}

Two conclusions can be drawn from the preceding section. First, for a prison system to be adopted by a society it is not sufficient that its members know about the possibility; the structure of the society must somehow be receptive to it. Second, the discovery of the asylum does not necessarily coincide with the emergence of prisons; in Europe and, to a lesser extent, in America the former antedated the latter. The difference in timing between Europe and America was simply due to the later start of the white societies in the New World. Of course a later start does not necessarily mean late forever. Ideas, technologies and institutions sometimes do migrate from one type of society to another. By the late nineteenth century the North-Eastern part of the USA resembled contemporary Western Europe in many respects. When discussing the rise of imprisonment in America, we have to keep in mind both the late start and the rapid catching up.

As noted above, an embryonic form of imprisonment appeared already in Colonial times. From the second quarter of the eighteenth century onwards institutions resembling European houses of correction were set up in several places. The character of these institutions has not been clearly determined by historical research. Those established in Rhode Island, for example, do not seem to have been penal at all. ${ }^{57}$ Connecticut's house of correction in 1727, on the other hand, was meant, among other things, for rogues, vagabonds and beggars. ${ }^{58}$ The institution inaugurated in New York in 1736 recalls the Dutch houses of correction in the early years of their existence. Its mixed purpose was threefold: confinement on request of disobedient servants and slaves; poor-relief; imprisonment of beggars, runaway servants and petty offenders condemned at the quarter sessions. In 1775 a new prison was built, which was called the bridewell. ${ }^{59}$ It looks as if the coastal towns of New England and the middle colonies made a tentative start with imprisonment in the eighteenth century. Although Rothman's apparent view that these places were all almshouses is hard to accept, he is probably right in stating that we should not overestimate their importance. Penal imprisonment, when it occurred, continued to be executed primarily in jails. Convicts were locked up in the company of debtors and persons under trial in places not very different from an ordinary residence. ${ }^{60}$ Between 1691 and 1776 the New York Supreme Court pronounced a prison sentence only nineteen or twenty times. Terms varied from eleven days to a year and a half. ${ }^{61}$ Pennsylvania knew life imprisonment for certain felonies but it was hardly ever practiced. ${ }^{62}$ Preyer confirms that the prison played but a marginal role in the penal system of all colonies. ${ }^{63}$. 
The first penal changes after the Revolution which have drawn the attention of historians were those taking place in Philadelphia in the 1790's. Recent studies have dispelled the myths surrounding these events. For one thing, they were not exclusively due to Quaker influence. The society which effectively campaigned for the laws of 1789 and 1790 was dominated by Episcopalians. Second, the experiment with solitary confinement was a rather marginal event. In fact, solitary confinement was only meant for "the more hardened and atrocious offenders".64 Four out of 117 prisoners condemned in 1795 met this qualification and seven out of 159 in $1796 .{ }^{65}$ Imprisonment in the Walnut Street cellhouse thus recalled an earlier Amsterdam practice: in the rasphouse separate confinement had been used from time to time as a disciplinary punishment. The Philadelphia episode was largely over by 1800 when the Walnut Street facility had become overcrowded and in bad state of repair. ${ }^{66}$ It was only around 1830 , when the penitentiaries in Pittsburgh and Cherry Hill were constructed, that the Pennsylvania system came into existence. ${ }^{67}$ Both penitentiaries were designed - rebuilt in the case of Pittsburgh - by the architect John Haviland, who based his designs on a mixture of European models. ${ }^{68}$.

By then imprisonment had become a regular practice. Around 1800 prisons were built in several states, but little is known about these early institutions, except in the case of New York. ${ }^{69}$ Newgate in Greenwich Village was the first criminal prison in America, receiving felons, of both sexes, only. Just as in Walnut Street, overcrowding soon led it to be considered unsatisfactory. ${ }^{70}$ The influx of prisoners reached notorious proportions because of a crime wave in the aftermath of the war with England. As a result, the number of prosecutions increased markedly, for offenses for which imprisonment had become the prescribed penalty in the meantime. ${ }^{71}$ This formed the immediate cause for the construction of Auburn, which took place between 1816 and 1823. Two years later its prisoners built Sing Sing. 72

With Auburn and Sing Sing established, the 'classical' era of American imprisonment had begun. According to Rothman, the 1820's and 1830's constituted the first period that witnessed the building of penal institutions on a large scale. ${ }^{73}$ Most other states took New York as their model. The most conspicuous features of Auburn and Sing Sing were congregate labor, coupled with a rule of strict silence and a regime of discipline and humiliation. Their introduction was associated especially with Elam Lynds, who became deputykeeper of the former institution in 1819. Thus both the Pennsylvania and Auburn systems were in operation by the time when the French inspector-general Charles Lucas published his comparative study of prisons in the USA and Europe and Tocqueville and Beaumont set out on their voyage. ${ }^{74}$ Europeans particuarly admired the Pennsylvania-style. ${ }^{75}$

The empirical evidence on the beginnings of penal imprisonment in America raises two basic questions. First, why did the prison emerge in the 1820's? Second, why was it that, although Europeans primarily admired the Pennsylvania system, most American prisons were modeled after Auburn? Both questions can be answered by taking the evidence from early modern Europe into account.

The first question has wider implications than an inquiry into concrete, immediate causes such as the crime wave in New York referred to above. We 
SPIERENBURG, PIETER, From Amsterdam to Auburn: An Explanation for the Rise of the

Prison in Seventeenth-Century Holland and Nineteenth-Century America, Journal of Social History, 20:3 (1987:Spring) p.439

FROM AMSTERDAM TO AUBURN

want to know in which respects the social structure of the early nineteenth century differed from that in the late seventeenth. An explanation in terms of Jacksonian democracy, whatever the merits of that concept, would still remain within the sphere of immediate causes. Moreover, the entirely different political context in which European houses of correction were founded, makes it hard to see this as the cause for the emergence of imprisonment in general. At first sight, economic developments are better suited to serve as an explanatory factor for the rise of prisons. A number of American scholars have argued for that connection. Miller, for example emphasizes that the hard-pressed shoemakers were disproportionately represented among the early prison population: "It hardly seems a coincidence that the shoemakers who were experiencing enormous stress and dislocation in free society were also coming to prison in disproportionate numbers. The prison held a message of deterrence out to the 'undisciplined' workers. The somber penitentiary, the symbol of state coercion at its greatest control and severity, would serve the interests of the emerging capitalist market economy by providing the ultimate 'correction' to the refractory worker. ${ }^{\text {m6 }}$

This type of argument, however, does not lead to a satisfactory explanation. For one thing, it is hardly surprising that repression particularly hit those groups who were in an unfavorable economic position. This also happened at times and places where imprisonment did not figure in the penal system. When houses of correction were established in Amsterdam, it was the marginal population of beggars and vagabonds who were hit hardest. We have to explain why the authorities came to look for a spatial solution to the problems of marginality. This might be because a certain stage of economic growth had been reached, but the comparison between Holland and America renders such a thesis less plausible. In seventeenth-century Europe commercial capitalism prevailed, while the nineteenth-century American North-East witnessed the beginnings of industrialism. If economic processes do not provide the primary explanation, the next step is to inquire whether my argument about state formation processes, developed from the European evidence, can also be valid for America.

Only two authors argue from that point of view. According to Takagi, the essence of the Walnut Street episode was a penal reform designed to give the state more control over repression. ${ }^{77}$ The state, of course, is Pennsylvania. Hindus likewise deals with two of the units making up the federation. Massachusetts quickly adopted the new prison system, but antebellum South Carolina had no need for it at all. The two states also differed on other accounts: "Massachusetts consistently sought to bolster the role of formal authority by strengthening its courts, establishing police, and curbing extralegal violence. In South Carolina, however, plantation aristocrats mocked court laws, took their quarrels to the dueling field instead of the courthouse, belatedly established police, supported permanent vigilante organizations, and actually encouraged citizens to find extralegal accommodations rather than increase strife through lawsuits." ${ }^{78}$

Thus both Hindus and Takagi suggest that state formation is an important factor in the rise of imprisonment in America, but they do not provide an analysis of the longer-term process. Takagi refers to a change consisting of judicial centralization, at the expense of the counties, in one of the thirteen ex-colonies. Centralization is an aspect of state formation processes, but not of their earliest 
SPIERENBURG, PIETER, From Amsterdam to Auburn: An Explanation for the Rise of the

Prison in Seventeenth-Century Holland and Nineteenth-Century America, Journal of Social History, 20:3 (1987:Spring) p.439

phases. In these processes monopolization of violence is the primary element. This aspect has hardly been made an object of systematic study by American historians. Although a literature exists on violence in American history, few studies view the subject from a developmental perspective. Ever since Turner, frontier violence has been considered as a somewhat unfortunate concomitant of the emerging American democracy. It is seldom realized that every region settled successively by whites experienced that development from stateless society to pacified centrally ruled area, which Europe took some seven centuries to complete. At the beginning of this development stood the vigilante movement. The vigilance committee functioned as a private domain of authority and violence in a single community under the leadership of the local elite. ${ }^{79}$ The de facto fragmentation of authority of which it was an expression, equally prevailed in medieval Europe.

The observations on vigilantism and the differences between regions in America provide a solution to the problem of the emergence of prisons. Late medieval Europe, provincial New York in the middle of the eighteenth century and antebellum South Carolina all witnessed roughly the same degree of (non-) monopolization of violence. The mocking of courts, noted by Hindus, was equally a feature of late medieval Europe..$^{80}$ And Douglas Greenberg makes clear that the colony of New York witnessed a high level of private violence and absence of state control up into the 1760 's. ${ }^{81}$ At the beginning of the nineteenth century a larger area in the North-East had become relatively pacified, but in the South this took a longer time. Thus Holland around 1600 and North-East America in the 1820 's, despite many differences, resembled each other in so far as both had recently emerged as relatively pacified entities. The coastal towns of the North had made a tentative start with imprisonment in late Colonial times, because they constituted a more or less settled and pacified fringe. When the North-East as a whole had become pacified the take-off of imprisonment began.

With the problem of the rise of the prison in America solved, it is possible to formulate an answer to the second question. The diverging preferences on either side of the Atlantic can be explained when early modern developments are taken into account. Rusche and Kirchheimer did so almost a half century ago, but they argued from a rather simplistic economic determinism. ${ }^{82} \mathrm{My}$ own argument stays within the theoretical framework outlined above and, consequently, serves to reinforce it. It is not surprising that Europeans were less excited by the Auburn system, since they had known it for two centuries. It was basically the regime of the house of correction. It is true that the Amsterdam rasphouse neither had a rule of silence nor separated prisoners at night. But its earliest ordinance included such rules as a prohibition of cursing. On the whole, strict regulation characterized the Dutch and German foundations. Just as these earlier institutions, the Auburn-style prisons were in practice workhouses where a severe labor discipline was enforced by the whip. ${ }^{83}$ This rather tough repression served the needs of societies which were recently pacified.

The most distinguishing characteristic of the Pennsylvania system was the possibility of solitary confinement twenty-four hours a day. This had not been invented in Philadelphia. English reformers, notably John Howard, had advocated comparable measures and their ideas were echoed by Americans such as Benjamin Rush. ${ }^{84}$ In early nineteenth-century Europe the principle of solitary 
SPIERENBURG, PIETER, From Amsterdam to Auburn: An Explanation for the Rise of the

Prison in Seventeenth-Century Holland and Nineteenth-Century America, Journal of Social History, 20:3 (1987:Spring) p.439

FROM AMSTERDAM TO AUBURN

confinement was discussed extensively, as European policy makers wished to experiment with new forms of imprisonment. Most Americans did not want to experiment; they were just starting with the prison and the Auburn-style suited them well. The Pennsylvania-style remained a minority-system because it served the needs of its society less adequately. In Europe, on the other hand, the rise of the nation-state had brought about a new transformation in repression, as explained at the end of the second section. Mind control became a major objective, and solitary confinement fit into this model. That is why Europeans admired Pennsylvanian practice. Tocqueville explained: "punishment here (...) is only directed at a man's mind, but it exerts an incredible influence upon him. ${ }^{\text {n85 }}$

It is easy to be misled by the popularity of American prisons with European visitors. These were not the same kind of people who had flocked to Amsterdam two centuries earlier. The visitors to Holland belonged to the general public; they came for other purposes and saw the houses of correction on their way. Nineteenth-century Europeans visiting American prisons were largely professionals. They were surveying and classifying, in accordance with the emerging 'science' of penology and they were equally interested in new institutions on their own continent. Just as many professionals went to see Geneva's prison, for example. ${ }^{86}$ American prisons served as models because Europeans, going through a phase of experimentation, were seeking models. Amsterdam's houses of correction, on the other hand, were exemplary because the city had made what was practiced elsewhere as well into a more elaborate and refined system.

To conclude, it should be noted that in certain respects America did not lag behind Europe. Some penal changes could apparently take effect in spite of a different social context. The humanitarian rhetoric, for example, that became common in Europe from the late eighteenth century onwards, was easily picked up by philanthropists on the other side of the Atlantic. Around 1800 several American states adopted new penal codes which established imprisonment as the penalty for many offenses and reduced the role of corporal punishment. In America legal change preceded the rise of the prison. In Europe, on the other hand, houses of correction had simply been opened without any noteworthy change in formal legislation. For about two centuries the scaffold was used alongside with the prison. North-East America passed over this intermediary phase and, from the beginning, acknowledged imprisonment as the main form of punishment. This did not so much imply a reduction of the physical element in repression, since a stern discipline continued to be enforced within prisons. Consequently, it rather meant a reduction of the public character of repression, substituting physical coercion indoors for the confrontation with the community. The fact that North-East America very rapidly started to execute the death penalty also indoors, is in line with this observation. Massachusetts abolished public executions in 1835, which is earlier than any European country. 87

The privatization of repression apparently did not necessarily require a preceding evolution of imprisonment. In America it was realized very smoothly during the early years when the prison had appeared on the scene. Consequently, by the latter half of the nineteenth century, there were few outward signs of a difference in modes of repression between the Old World and the New. Both routinely imprisoned delinquents and both witnessed a workers' movement 
SPIERENBURG, PIETER, From Amsterdam to Auburn: An Explanation for the Rise of the

Prison in Seventeenth-Century Holland and Nineteenth-Century America, Journal of Social History, 20:3 (1987:Spring) p.439

against prison labor. ${ }^{88}$ They had arrived at that point, however, by different routes.

\section{Conclusion}

The comparison between Western Europe and North-East America has clarified the role of state formation processes in the development of penal systems. Monopolization of violence represents an early phase in these processes and it functioned as a necessary prerequisite for the emergence of the prison, a spatial solution for public order problems. This can be demonstrated for both societies. The take-off of imprisonment occurred just after each society had become a relatively pacified entity. Their early prisons were characterized by compulsory labor enforced through physical discipline.

But from the moment of pacification and the rise of the prison onwards their routes diverged. In Europe violence had been monopolized by monarchs and patriciates. They continued to exercise a relatively personal rule which laid stress on public forms of repression. Consequently the scaffold retained a prominent place alongside the prison for more than two centuries. This slow evolution may have influenced the desire for experimentation and mind control that became so outspoken around 1800 . America, on the other hand, hardly experienced this desire. Except in the Old South, monopolization of violence resulted very quickly in relatively impersonal and bureaucratic forms of rule. Consequently, public modes of repression were dispensed with entirely and the prison became the central institution of the penal system.

Erasmus Universiteit Rotterdam

Pieter Spierenburg

\section{FOOTNOTES}

An earlier version of this article was presented as a paper at the meeting of the Academy of Criminal Justice Sciences in Louisville, March 1982 and at the symposium "Politics, Economics and the Arts, the Netherlands and the Foundation of the American Republic" at UCLA, April 1982. I am grateful to the participants in both meetings, especially to the discussants, John Conley and Eric Monkkonen, for their comments.

1. Major publications include David J. Rothman, The Discovery of the Asylum. Social Order and Disorder in the New Republic (Boston 1971); and see also Conscience and Convenience. The Asylum and its Altematives in Progressive America (Boston, 1980). Michel Foucault, Surveiller et Punir. Naissance de la Prison (Paris, 1975). Michael Ignatieff, A Just Measure of Pain. The Penitentiary in the Industrial Revolution, 1750-1850 (New York, 1978). Hannes Stekl, Osterreichs Zucht- und Arbeitshäuser, 1671-1920. Institutionen zwischen Fürsonge und Strafoollzug (Vienna, 1978). Michelle Perrot, ed., LImpossible Prison. Recherches sur le Système Pénitentiaire au 19e Siècle.Débat avec Michel Foucault (Paris, 1980). Robert Roth, Pratiques Pénitentiaires et Théorie Sociale. LExemple de la Prison de Genève, 1825-1862 (Geneva, 1981). Jacques G. Petit, ed., La Prison, le Bagne et l'Histoire. (Geneva, 1984). Pieter Spierenburg, ed. The Emergence of Carceral Institutions: Prisons, Galleys and Lunatic Asylums, 1550-1900 (Rotterdam, 1984).

2. Compare Pieter Spierenburg, The Spectacle of Suffering. Executions and the Evolution of Repression: from a Preindustrial Metropolis to the European Experience (Cambridge, 1984): 183-5. A good example of a precise analysis in which humanitarian thetoric is taken seriously is Randall 
SPIERENBURG, PIETER, From Amsterdam to Auburn: An Explanation for the Rise of the

Prison in Seventeenth-Century Holland and Nineteenth-Century America, Journal of Social History, 20:3 (1987:Spring) p.439

FROM AMSTERDAM TO AUBURN

McGowen, "Humanitarianism and Criminal Law Reform in Early Nineteenth-Century England" (Paper presented at the conference "The History of Law, Labour and Crime," University of Warwick 1983).

3. Rothman, Discovery of the Asylum.

4. For example Martin B. Miller, "At Hard Labor: Rediscovering the 19th Century Prison," Issues in Criminology 9, 1 (1974): 91-114. John Conley, "Prisons, Production and Profit: Reconsidering the Importance of Prison Industries," Joumal of Social History 14, 2 (1981): 257-75; see also "Revising Conceptions about the Origin of Prisons: The Importance of Economic Considerations." Social Science Quarterly 62, 2 (1981): 247-58: and also "Economics and the Social Reality of Prisons," Joumal of Criminal Justice 10 (1982): 25-35.

5. Foucault, Surveiller et Punir; Stekl, Öterreichs Zucht-und Arbeitshäuser, 1671-1920; Ignatıeff, A Just Measure of Pain.

6. Pieter Spierenburg, "Model Prisons, Domesticated Elites and the State: The Dutch Republic and Europe," in Göran Rystad, ed., Europe and Scandinavia. Aspects of the Process of Integration in the 17th Century (Lund, 1983), pp. 219-35; see also The Emergence of Carceral Institutions and the contribution with Diederiks in Petit, La Prison, Le Bagne et et l'Histoire, pp. 43-55.

7. Georg Rusche and Otto Kirchheimer, Punishment and Social Structure (New York, 1939).

8. Michel Foucault, Folie et Déraison, Histoire de la Folie à l'Age classique (Paris, 1961); see also Surveiller et Punir.

9. More detailed information on this subject is to be found in Spierenburg, The Emergence of Carceral Institutions; and in the works listed in the bibliography of my own essay in that volume. That essay forms the reference for most of the data discussed in the first section of the present article.

10. Joanna Innes, "The King's Bench Prison in the Later Eighteenth Century: Law, Authority and Order in a London Debtor's Prison." in: John Brewer and John Styles eds., An Ungovemable People. The English and Their Law in the Seventeenth and Eighteenth Centuries. (London, 1980) pp. 250-98.

11. Spierenburg, The Emergence of Carceral Institutions: pp. 16-24.

12. Herman Diederiks, "Patterns of Criminality and Law Enforcement during the Ancien Regime: The Dutch Case," Criminal Justice History I (1980): 281.

13. Stekl, Österreichs Zucht- und Arbeitshäuser, 1671-1920.

14. Cf. Zysberg in Spierenburg, The Emergence of Carceral Institutions: pp. 78-124.

15. A. Hallema, In en om de Gevangenis. (Den Haag, 1936): 32; Amstelodamum, Maandblad, 1939: 181-2 and 1940: 21-2 and 1962: 6-9. In most cases the place of publication is unknown, but at least one pamphlet was printed at Augsburg in 1630.

16. Jan Van Hout, "Rapporten en Adviezen betreffende het Amsterdamse Tuchthuis," ed. A. Hallema, Bijdragen en Mededelingen van het Historisch Genootschap 48 (1927): 69-98; A. Hallema, "Het Amsterdamse Tuchthuis in 1710," Jaarboek Amstelodamum 45 (1953): 183-92.

17. J.H. Jacobsen Jensen, Reizigers te Amsterdam. Beschrijuende Lijst van Reizen in Nederland door Vreemdelingen voor 1850. (Amsterdam, 1919) (Supplement, Amsterdam, 1936).

18. Johannes Isacius Pontanus, Historische Beschrijvinghe der seer wijt beroemde Coop-Stadt 
SPIERENBURG, PIETER, From Amsterdam to Auburn: An Explanation for the Rise of the

Prison in Seventeenth-Century Holland and Nineteenth-Century America, Journal of Social History, 20:3 (1987:Spring) p.439

Amsterdam (Amsterdam, 1614). I am referring to the Dutch edition. The original Latin one was published in 1611 .

19. Pontanus, Historische Beschrijuinghe: pp. 132 et seq.

20. Historie Van de wonderlijcke mirakelen die in menichte ghebeurt zijn ende noch dagelijcx ghebeuren binnen de vermaerde Coopistad Aemstelredami In een plaers ghenaempr het Tuche-huys, ghelegen op de Heylighewegh (Amsterdam 1612).

21. Handvesten, Ofte Privilegien ende Octroyen mitsgaders Willekeuren, Costumen, Ordonnantien en Handelilngen der Stad Amstelredam. 3 vols. (Amsterdam, 1748), p. 456. In the same year (1614) the Estates of Holland issued a placard against begging: cf. Groot-Placcaatboek: 14.

22. J.J.Th. Poederbach, "Het Armenhuis der Stad Amsterdam. Tevens Een en Ander uit den Strijd Tegen de Bedelarij in Vroeger Dagen," Jaarboek Amstelodamum 18 (1920): 71-142 (72-83).

23. Gemeente-Archief Amsterdam, Keurboek M: fo. 197 vs.

24. Olfert Dapper, Historische Beschryuing der Stadt Amsterdam (Amsterdam 1663), pp. 425-32.

25. Hans Bontemantel, De Regeeringe van Amsterdam, soo in't Civiel als Crimineel en Militaire (1653-1672). Ed. G.W. Kernkamp, (2 vols.) ('S Gravenhage, 1897), I, 274-5.

26. Casparus Commelin, Beschrijvinge van Amsterdam. 2 vols. (Amsterdam, 1693): foreword \& 507. To be sure, Jan Wagenaar, Amsterdam in zone Opkomst, Aanwas, Geschiedenissen, Voorregten, Koophandel, Gebouwen, Kerkenstaat, Schoolen, Schutterye, Gilden en Regeeringe. 13 vols. (Amsterdam, 1760-1768), writing in the 1760's, again groups them with the godshuizen (vol. 8 pp. 233 et seq.) but he was more of an historian.

27. Dapper, Historische Beschryving der Stadt Amsterdam (Amsterdam, 1663), pp. 419-20; Bontemantel, De Regeeringe van Amsterdam, I, p. 281.

28. Dapper, Historische Beschryving de Stadt Amsterdam (Amsterdam, 1663), pp. 425-32.

29. Jean Jüngen, Een Stad van Justitie? (MA - thesis, Vrije Universiteit, Amsterdam, 1979) pp. 25 and $63-4$.

30. The sources are the sententie- justitie- and confessieboeken in the Gemeente-archief of Amsterdam, from which the tables 2 and 3 were compiled.

31. About five pct. of the cases in all three samples led to a sentence of a short term on bread and water in jail. These sentences are not included in the figures of table $2 \mathrm{~B}$.

32. Compare Miller, "At Hard Labor," 91-114.

33. This is discussed in more detail in Spierenburg, The Spectacle of Suffering: pp. 183-99.

34. Rod Morgan, "Divine Philanthropy: John Howard Reconsidered," History 62 (1977): (401).

35. Quotation from the inaugural statutes: J.A. van der Chijs, Nederlandsch Indisch Plakaatboek. Eerste Deel, 1602-1642 (Batavia, Den Haag, 1885) p. 576.

36. The inmates were indeed obliged to spin. The status of most Dutch women, however, ensured that they owned slaves, who accompanied them into the spinhouse to do the work.

37. Carl Bridenbaugh, Cities in the Wilderness. The First Century of Urban Life in America (New York, 1955), 73. 
SPIERENBURG, PIETER, From Amsterdam to Auburn: An Explanation for the Rise of the

Prison in Seventeenth-Century Holland and Nineteenth-Century America, Journal of Social History, 20:3 (1987:Spring) p.439

\section{FROM AMSTERDAM TO AUBURN}

38. Plakkaatboek van Nieuw-Nederland (transcript at the Gemeentearchief of Amsterdam, film nr. 3637), 11 July 1642. See also Scott Christianson "Criminal Punishment in New Netherland" (paper prepared for the Rensselaerswyck Seminar III, (Albany 1980): p. 6.

39. A. Hallema, "Nederlandse Invloeden op en Voorbeeld voor het Buitenlands Gevangeniswezen tijdens de Republiek," Tijdschrift voor Geschiedenis 69 (1956): 55.

40. Julius N. Goebel Jr., "The Courts and the Law in Colonial New York" in David Flaherty (ed.), Essays in the History of Early American Law (Chapel Hill, N.C., 1969) 247.

41. The Amsterdam gemeente-archief has copies of all the records.

42. Edmund N. O'Callaghan, Calendar of Historical Manuscripts in the Office of the Secretary of State (Albany, 1865) X, 2, p. 466.

43. Gemeente-Archief Amsterdam, New Netherland Council Minutes: 1663.

44. Christianson, "Criminal Punishment" p. 7, expresses the same opinion.

45. Lawrence John Decker, On Pain of Arbitrary Punishment. Court, Crime and Punishment at a Seventeenth Century Frontier Community (paper) p. 14.

46. Bridenbaugh, Cities in the Wilderness p. 75.

47. Ibid: 74.5 and 82 . In 1680 the court of New York decided to build a prison for drunken Christians and Indians but nothing much came of it Cf. Julius N. Goebel jr., and T. Raymond Naughton, Law Enforcement in Colonial New York (New York, 1944): p. 690.

48. Albert Deutsch, The Mentally $11 l$ in America. A History of their Care and Treatment from Colonial Times (New York, 1937): p. 53.

49. Bridenbaugh, Cities in the Wilderness, p. 84.

50. Rothman, The Discovery of the Asylum, pp. 30-1.

51. Gary B. Nash, "Poverty and Poor Relief in pre-Revolutionary Philadelphia;" William and Mary Quarterly 33 (1976): 3.30 (18-9)

52. Amsterdam's major contribution to the system of repression in New Amsterdam was the latter's adoption of the rattle-watch, which functioned between 1658 and 1682 . This watch, however, was on the lookout for Indians rather than for burglars. Bridenbaugh, Cities in the Wildemess, pp. 65 and 67; James F. Richardson, The New York Police. Colonial Times to 1901 (New York, 1970), p. 8.

53. Michael Kammen, Colonial New York: A Histony (New York, 1975): p. 73.

54. Deutsch, The Mentally III in America: p. 52.

55. To be sure, the West India Company forced a tolerant and liberal policy on Stuyvesant. Cf. George F. Smith, Religion and Trade in New Netherland, Dutch Origins and American Development (Ithaca, 1973): p. 23.

56. Kammen, Colonial New York: p. 73.

57. Lynne Withey, "Crime, Poverty and Perceptions of Deviance in a Commercial Economy: The Case of Eighteenth-Century Rhode Island" (Paper prepared for the C3-theme of the 7th International Economic History Congress, Edinburgh, 1978), pp. 143-5. 
SPIERENBURG, PIETER, From Amsterdam to Auburn: An Explanation for the Rise of the

Prison in Seventeenth-Century Holland and Nineteenth-Century America, Journal of Social History, 20:3 (1987:Spring) p.439

58. Deutsch, The Mentally $11 l$ in America, p. 52.

59. Arthur Everett Peterson and George William Edwards, New York as an Eighteenth Century Municipality (New York, 1917): pp. 98-9 and 103. A mixture of poor-relief and penal purposes also characterized the Philadelphia bettering house, opened in 1767. Cf. Nash, Poverty and poor-relief, pp. 15-27.

60. Rothman, The Discovery of the Asylum, pp. $35-45$ and 52-6.

61. Goebel/Naughton, Law Enforcement in Colonial New York (New York, 1944): pp. 702-3 (note 139) count 20 cases. Douglas Greenberg, Crime and Law Enforcement in the Colomy of New York 1691-1776 (Ithaca, 1976): p. 125 (note 53) counts 19 cases.

62. Herbert William Keith Fitzroy, "The Punishment of Crime in Provincial Pennsylvania," Pennsyluania Magazine of History and Biography 60 (1936): 258.

63. Kathryn Preyer, "Penal Measures in the American Colonies: An Overview," American Joumal of Legal History 26 (1982).

64. Paul Takagi, "The Walnut Street Jail: A Penal Reform to Centralize the Powers of the State," Federal Probation 39, 4 (1975): 18-26.

65. Negley K. Teeters, The Cradle of the Penitentiary. The Walnut Street Jail of Philadelphia, 1773-1835 (Philadelphia, 1955): p. 39.

66. Martin B. Miller, "Crime, Convicts and Penitentiaries of the North-East 1825-1838" (Paper presented at the meeting of the Academy of Criminal Justice Sciences, Louisville, KY, March 1982): 3.

67. Although even Western penitentiary in Pittsburgh was soon found to be unfit for solitary confinement: Miller, "Crime, Convicts and Penitentiaries:" pp. 1-2.

68. Miller, "At Hard Labor: Rediscovering the 19th Century Prison." Issues of Criminology 9, 1 (1974): 95.

69. Blake McKelvey, American Prisons. A Study in American Social History prior to 1915 (Chicago, 1936): p. 7.

70. Walter David Lewis, From Newgate to Dannemora. The Rise of the Penitentiary in New York, 1796-1848 (Ithaca, 1965): pp. 29.53.

71. Ibid: 54-5; Miller, "Sinking Gradually into the Proletariat: the Emergence of the Penitentiary in the United States." Crime and Social Justice (1980): 38.

72. Lewis, From Newgate to Dannemora, pp. 136-7.

73. Rothman, The Discovery of the Asylum; see also Michael Stephen Hindus, Prison and Plantation. Crime, Justice and Authority in Massachusetts and South Carolina, 1767-1878 (Chapel Hill, NC 1980): pp. 162-81 and Paul Boyer, Urban Masses and Moral Order in America, 1820-1920. (Cambridge, Mass 1978): pp. 94-6. Rothman's thesis of a relationship with Jacksonian democracy has been contested. See, for example, Martin Miller, "Sinking Gradually into the Proletariat," p. 37.

74. On Lucas: Jacques Petit, "LA'Amendement ou l'Entreprise de Rèforme Morale des Prisonniers en France au 19e Siècle," Déviance et Société 6, 4 (1982): 331-51 (340-6); on Tocqueville/Beaumont: Perrot in Petit, La Prison le Bagne et l'Histoire. pp. 103-13. 
SPIERENBURG, PIETER, From Amsterdam to Auburn: An Explanation for the Rise of the

Prison in Seventeenth-Century Holland and Nineteenth-Century America, Journal of Social History, 20:3 (1987:Spring) p.439

\section{FROM AMSTERDAM TO AUBURN}

75. Which has been noted by many authors; see, for example, Kai T. Erikson Wayward Puritans. A Study in the Sociology of Deviance (New York, 1966): p. 204; Miller, "At Hard Labor," p. 96; Thomas O. Murton, The Dilemma of Prison Reform (New York 1976): pp. 8-9.

76. Miller, "Sinking Gradually into the Proletariat," p. 41. See also Miller, "Crime, Convicts and Penitentiaries," 11-12.

77. Takagi, "The Walnut Street Jail:" p. 24.

78. Hindus, Prison and Plantation, p. xxvi. See also the review by Eric Monkkonen (Indiana Law Journal 56,2: 273) who is critical of Hindus' notion of weak and strong states. Just after completing this article I got a copy of Edward L. Ayers, Vengeance and Justice. Crime and Punishment in the 19th Cencury American South (New York, 1984). In chapter 2 Ayers explains that several states in the Old South did in fact establish prisons, so that South Carolina may have been rather exceptional.

79. Richard Maxwell Brown, Strain of Violence. Historical Studies of American Violence and Vigilantism (New York, 1975): pp. 95-133. Brown's work comes closest to an analysis of the process of pacification in America, but in the end it appears to have been written from a static perspective. Brown essentially argues for a sort of culture of violence present throughout American history. See, for example, pp. 3-36 and also 56-63 where the association violencedemocracy turns up.

80. Spierenburg, The Spectacle of Suffering, pp. 6.8.

81. Greenberg, Crime and Law Enforcement, pp. 156-87.

82. Rusche/Kirchheimer, Punishment and Social Structure, pp. 127-37. This type of economistic argument was recently taken up anew by Dario Melossi and Massimo Pavarini, The Prison and the Factory. Origins of the Penitentiary System (London, 1981).

83. Rothman, The Discovery of the Asylum, pp. 101-2.

84. Ignatieff, A Just Measure of Pain, pp. 93-8; see also Takagi, The Walnut Street Jail, p. 21.

85. Quoted by Michelle Perrot in Petit, La Prison, le Bagne et l'Histoire, p. 107.

86. Roth, Pratiques Pénitentiaires et Théorie Sociale.

87. Hindus, Prison and Plantation, p. 201; on the abolition of public punishment in Europe: Spierenburg, The Spectacle of Suffering, pp. 196-9.

88. See, for example, Miller, "At Hard Labor:" pp. 103-4; Gordon Wright, Between the Guillotine and Liberty. Two Centuries of the Crime Problem in France (New York, 1983): pp. 162-6. 
SPIERENBURG, PIETER, From Amsterdam to Auburn: An Explanation for the Rise of the Prison in Seventeenth-Century Holland and Nineteenth-Century America , Journal of Social History, 20:3 (1987:Spring) p.439 